\title{
Floristic composition and species diversity in three habitat types of heath forest in Belitung Island, Indonesia
}

\author{
DINA OKTAVIA ${ }^{1, \bullet}$, SANTI DWI PRATIWI ${ }^{2}$, SITI MUNAWAROH ${ }^{3}$, AGUS HIKMAT $^{4}$, IWAN HILWAN ${ }^{5}$ \\ ${ }^{1}$ Department of Environmental Science, Graduate School, Universitas Padjadjaran. Jl. Dipatiukur 35, Bandung, West Java, 40132, Indonesia. \\ Tel./fax.: +62-22-84288828, `email: dina.oktavia@unpad.ac.id \\ ${ }^{2}$ Department of Geosciences, Faculty of Geological Engineering, Universitas Padjadjaran. J1. Raya Bandung-Sumedang Km. 21, Jatinangor, Sumedang \\ 45363, West Java, Indonesia \\ ${ }^{3}$ Directorate of Forestry Planning and Environmental Management, Ministry of Forestry and Environment. J1. Raya Pasir Padi, Kota Pangkalpinang \\ 33149, Kepulauan Bangka Belitung, Indonesia \\ ${ }^{4}$ Department of Forest Resources Conservation and Ecotourism, Faculty of Forestry and Environment, Institut Pertanian Bogor. Jl. Ulin, Lingkar \\ Akademik, IPB University Campus Dramaga, Bogor 16680, West Java, Indonesia \\ ${ }^{5}$ Department of Silviculture, Faculty of Forestry and Environment, Institut Pertanian Bogor. Jl. Ulin, Lingkar Akademik, IPB University Campus \\ Dramaga, Bogor 16680, West Java, Indonesia
}

Manuscript received: 21 October 2021. Revision accepted: 26 November 2021.

\begin{abstract}
Oktavia D, Pratiwi SD, Munawaroh S, Hikmat A, Hilwan I. 2021. Floristic composition and species diversity in three habitat types of heath forest in Belitung Island, Indonesia. Biodiversitas 22: 5555-5563. Exploring plant diversity, structure, and composition of vegetation in forest ecosystems is necessary for understanding the mechanism of species coexistence and forest dynamics, moreover in a unique and vulnerable ecosystem such as tropical heath forest (kerangas). We investigated the composition and structure of vegetation of heath forests in East Belitung, Indonesia in three habitat types, namely primary heath forest (rimba), secondary heath forest (bebak), and grassland (padang). Vegetation analysis was conducted using the combination of transect and plot method to calculate the importance value index (IVI) for all species and biodiversity indicators for each habitat type. We recorded 157, 135, and 31 species in rimba, bebak, and padang, respectively. The top three dominant families of species found were Myrtaceae, Clusiaceae, and Euphorbiaceae. In rimba, Syzygium lepidocarpa had the highest IVI for seedlings, Calophyllum lanigerum had the highest IVI for saplings, and Schima walichii had the highest IVI for trees. In bebak, Guioa pleuropteris had the highest IVI for seedlings, Garcinia hombroniana had the highest IVI for saplings, and Schima walichii had the highest IVI for trees. In padang, Fimbristylis sp. had the highest IVI for seedlings, while Leptospermum flavescens had the highest IVI for saplings and trees. Some pioneer species were found such as Rhodomyrtus tomentosa, Rhodamnia cinerea, Syzygium buxifolium. We also found two carnivorous plants Drosera burmannii and Nepenthes gracilis in padang, indicating that this habitat type is poor in nutrients in the soils. We suggested that the presence of species composition in the three habitat types of heath forest is an essential plant resource to be conserved and sustainably utilized. Establishing reserve areas to protect natural habitat and biodiversity is encouraged to provide proper ecosystem function for the people and nature.
\end{abstract}

Keywords: Conservation, heath forest, kerangas forest, Myrtaceae, plant diversity, vegetation analysis

\section{INTRODUCTION}

Heath forest (kerangas) is a forest ecosystem type in a tropical region that grows on podzolic soil with a sandy texture, poor in nutrients and has low pH (Katagiri et al. 1991; Luizão et al. 2007; Oktavia et al. 2015). The vegetation of heath forest is generally characterized by a high density of vegetation, presence of carnivorous plants, woody liana, and the size of trees trunk is relatively small (Brunig 1974; Davies and Becker 1996). This condition indicates that heath forest is vulnerable to disturbance and difficult to restore once degraded (Becker and Wong 1993; Tyree et al. 1998; Hattori et al. 2019). Therefore, in Indonesia, heath forest is protected and belongs to the high conservation value ecosystem because of the uniqueness of the ecosystem and its ecological function.

The distribution of heath forests in Indonesia can be found in Sumatra and Kalimantan (Whitten et al. 1984 and Mackinnon et al. 1996). One of the regions in Indonesia that has heath forests in Sumatra is Belitung Island
(Whitmore 1984). This island is globally also recognized as a part of the savanna corridor in Sundaland (Bird et al. 2005). The heath forest ecosystem might be the main forest ecosystem in Belitung Island, which stands almost entirely of Belitung Island (Whitten et al. 1984). However, the forest cover in Belitung is now under threat by the rapid development of rubber and oil palm plantations, mining of tin and quartz sand, illegal logging, and regional development. Despite its vulnerability to disturbance along with the threatening processes that occur in health forests including in Belitung, this ecosystem gets less conservation attention which might be able to the poor physical condition that gives the impression of unproductive land. (Becker and Wong 1993; Tyree et al. 1998).

The ecological mechanism associated with species diversity has long been a focus of ecological-based research. Abiotic interaction and habitat filtering are also thought to be important contributors to the formation of species communities (Chesson 2000). Many studies have shown that biotic stress is the primary limiting factor in the 
enhancement of species diversity during the early stages and species composition is influenced by a variety of edaphic influences (Sellan et al. 2019). In heath forests, the richness, structure, and composition of species are linked to edaphic and topographic factors, and soil acidity may play a significant role in shaping forest vegetation communities.

Understanding the structure and composition of tree vegetation is one of the parameters that must be considered in the management of the conservation forest ecosystem (Hossen et al. 2021; Onrizal et al. 2005; Templeton et al. 2019; Dodo and Hidayat 2020). This is particularly important for several reasons. Tree vegetation in a forest ecosystem plays a crucial role in providing and maintaining ecosystem services and biodiversity habitat, which has potential uses for bioprospecting. The condition of vegetation also provides insight on the state of intactness and degradation of a forest ecosystem to inform the conservation strategies, the needs for restoration, regenerative ability, and successional process in the present time and in the future (Budiharta et al. 2014).

Information of floristic composition in Belitung Island is necessary for future development, particularly to support conservation effort of heath forest and restoration activities when necessary. According to the traditional landscape in Belitung, there are three habitat types based on the successional stages, namely rimba (primary forest), bebak (secondary forest), and padang (grassland) (Fakhrurrazi 2001). Rimba is a natural ecosystem that grows on podsol soil type (tana teraja) in a relatively higher location, or in a humid/wet environment, while bebak is a successional forest that grows on community-owned land, usually a former field to cultivate Piper nigrum (Fakhrurrazi 2001). Padang is a special heath forest that is formed as a climax ecosystem after the heath forest is severed by fire disturbance (Whitten et al. 1984). This study aimed to identify the floristic composition, structure of trees species, and diversity in the three habitat types or vegetational conditions (i.e., primary forest, secondary forest, and grassland) of heath forest in Belitung Island.

\section{MATERIALS AND METHODS}

\section{Study area}

This study was conducted in East Belitung District, Belitung Island, Indonesia (Figure 1). The north side of East Belitung is bordered by the South China Sea and the south side is bordered by the Jawa Sea. The East Belitung District has a total area of approximately 250.691 ha.

Locations for data collection were on heath forest at three habitat types. The first is a primary heath forest (rimba) in the Gunung Sepang Protection Forest, Kelubi village, Manggar sub-district (Figure 2.A) and located at $02^{\circ} 46.833^{\prime} \mathrm{S}$ and $108^{\circ} 07.761^{\prime} \mathrm{E}$. The second is a secondary heath forest (bebak) in Kelubi village, Manggar sub-district (Figure 2.B) and located at $02^{\circ} 50.274^{\prime} \mathrm{S}$ and $108^{\circ} 09.450^{\prime} \mathrm{E}$. The third is a grassland (padang) in the Gunung Sepang Protection Forest, Kelapa Kampit sub-district (Figure 2.C) and located at $02^{\circ} 50.282^{\prime} \mathrm{S}$ and $108^{\circ} 09.208^{\prime} \mathrm{E}$.

\section{Data collection}

Vegetation data were collected using a combination of transect and plot methods (Kusmana 1997). Ten transects were established with the length of $100 \mathrm{~m}$, consisting of 10 observations plots measuring $10 \mathrm{~m} \times 10 \mathrm{~m}$ for each plot. The distance between the transects was $100 \mathrm{~m}$. Each observation plot was divided into three sub-plots to measure vegetation based on growth stages. Each individual plant found in the plot was measured stem diameter at breast height (DBH) using a tape diameter, then classified whether it included saplings or trees. Seedlings were defined as woody plants with a height $<1.5 \mathrm{~m}$ and were surveyed along with shrubs, herbs, and lianas at $2 \mathrm{~m} \times$ $2 \mathrm{~m}$ sub-plot. Saplings were defined as woody plants with height $>1.5 \mathrm{~m}$ and were surveyed at $5 \mathrm{~m} \times 5 \mathrm{~m}$ sub-plot. Trees were defined as woody plants with $\mathrm{DBH} \geq 10 \mathrm{~cm}$ and were surveyed at $10 \mathrm{~m} \times 10 \mathrm{~m}$ sub-plot. The DBH size was used as the basis for calculating the basal area for trees.

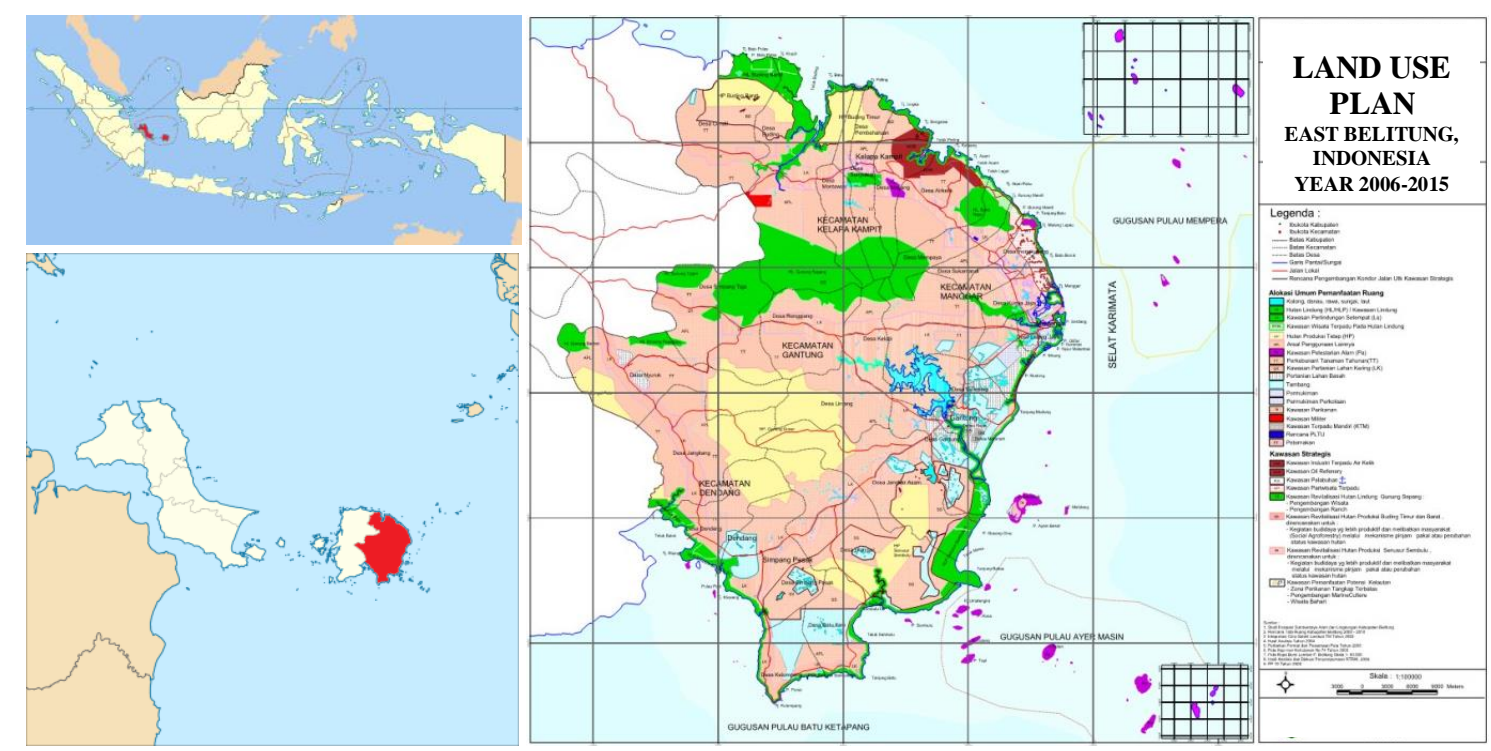

Figure 1. Map study site in East Belitung District, Kepualauan Bangka Belitung Province, Indonesia 


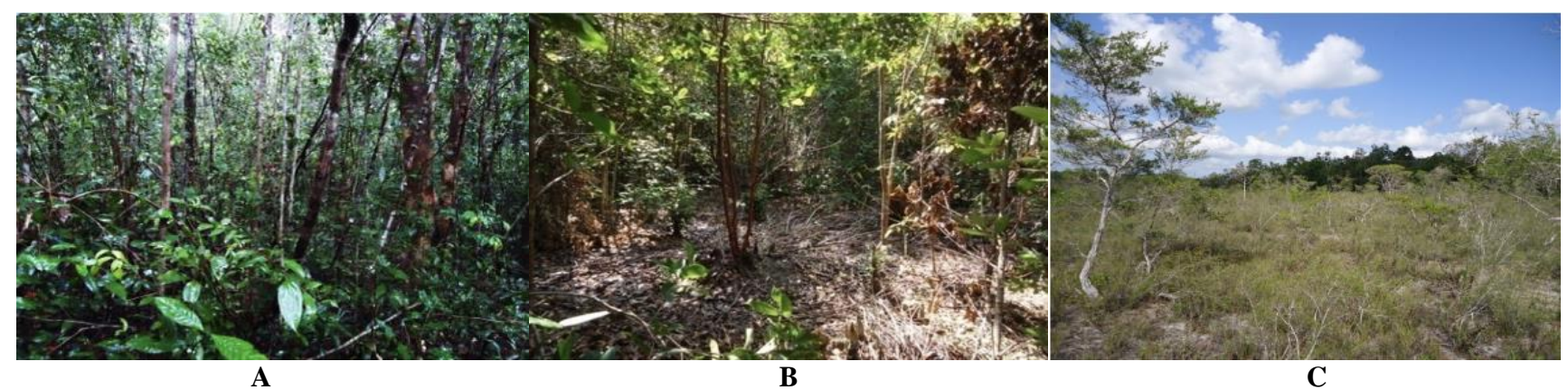

Figure 2. Three habitat types of heath forest observed in this study: A. Primary forest (rimba); B. Secondary forest (bebak); C. Grassland (padang)

Meanwhile, we only counted the number of individuals of each species for seedlings, shrub, herbs, liana, and sapling in each sub-plot. Some plant species were identified directly on the plots, while some other identifications were carried out by making herbarium specimens. Identification of herbarium collections was conducted at the Herbarium Bogoriense LIPI Cibinong, Bogor, Indonesia.

\section{Data analysis}

Importance value index (IVI)

The data obtained from the results of the vegetation analysis were analyzed quantitatively by calculating the Importance Value Index (IVI) of each species found. The IVI value has helped to understand the ecological significance of the species in community structure. The IVI of trees was the sum of relative density, relative frequency, and relative dominance, which ranges between 0 and 300 (Mueller-Dumbois and Ellenberg 1974). For seedlings and saplings, it was the sum of relative density and relative frequency, so that the maximum IVI would be 200. Basal area $\left(\mathrm{m}^{2}\right)$ is the area occupied by a cross-section of stem at breast height $=[3.14 \times(\mathrm{DBH} / 2) 2]$. We calculated relative density, relative frequency, and relative dominance as follows:

Density $=$ number of individual of species/ total number of sample plots

Relative density $=$ (number of individual species $\mathrm{A} /$ number of all individual species) $\times 100 \%$

Frequency $=$ number of quadrats with species $\mathrm{A} /$ total number of all quadrats

Relative frequency $=$ (frequency of species $\mathrm{A} /$ total frequency of all species) $\times 100 \%$

Dominance $=$ basal area of species $\mathrm{A} /$ total area sampled

Relative dominance $=($ dominance of species $\mathrm{A} /$ total dominance of all species) $\times 100 \%$

\section{Species diversity, richness, and evenness}

The diversity of plant species was determined using the Shannon Diversity Index (Ludwig \& Reynolds 1988) with the formula:

$$
\mathrm{H}^{\prime}=-\sum_{\mathrm{i}=1}^{\mathrm{s}} \mathrm{pi} \ln \mathrm{pi}, \text { where } \mathrm{pi}=\frac{\mathrm{ni}}{\mathrm{N}}
$$

Where, $\mathrm{H}^{\prime}$ is the diversity index community $\mathrm{A}$, ni is number of individuals of the $\mathrm{i}$ species, and $\mathrm{N}$ is the total number of individuals of all species

The larger of $\mathrm{H}^{\prime}$ of a community, the more stable the community is. The value of $\mathrm{H}^{\prime}=0$ can occur if there is only one species in one sample (sample) and maximum $\mathrm{H}$ if all species have the same number of individuals and this indicates a perfectly distributed abundance (Ludwig et al. 1988).

Species richness was measured using the Margalef Index (Ludwig et al. 1988) as follow:

$$
\mathrm{R}=\frac{\mathrm{S}-1}{\ln (\mathrm{N})}
$$

Where, $\mathrm{R}$ is the richness index of community $\mathrm{A}, \mathrm{S}$ is the total number of species, and $\mathrm{N}$ is the total number of individuals of all species.

For the evenness of species, it is used to determine the symptoms of dominance among each species in a location. The formula used to calculate the Evennes value (Ludwig et al. 1988) was:

$$
E=\frac{H^{\prime}}{\ln (S)}
$$

Where, $\mathrm{E}$ is the evenness index of community $\mathrm{A}, \mathrm{H}$ ' is the Shannon diversity index, and $\mathrm{S}$ is a total number of species.

\section{RESULTS AND DISCUSSION}

\section{Species richness of heath forest in three habitat types}

Plant community consists of a group of plants, each of which has its characteristics. We found 157, 135, and 31 species are rimba, bebak, and padang, respectively (Figure 3). In total, across the three habitats of heath forest three were 224 species belonging to 72 families of plants from various habitus (shrubs, herbs, and lianas) and tree growth stages (seedlings, saplings, and trees). 


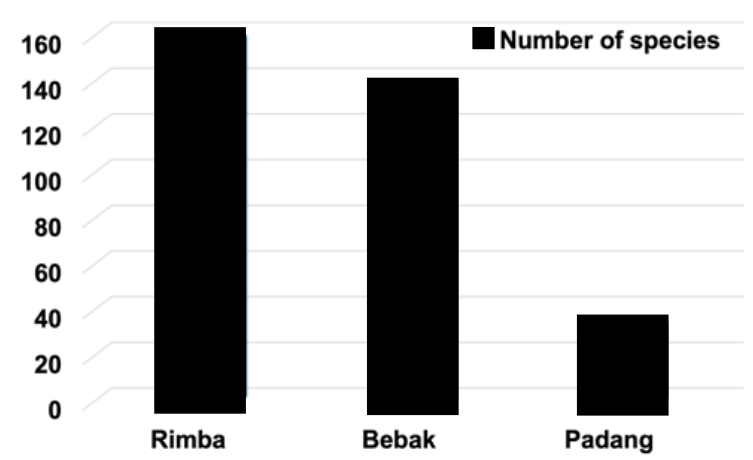

Figure 3. Number of species in three habitat types of heath forests (i.e., rimba, bebak, and padang) in East Belitung, Indonesia

Different types of ecosystems affect the number of species and individuals found (Vockenhuber et al. 2011; Laliberté et al. 2014). Plant species in rimba were dominated by tolerant and semi-tolerant species. The low number of pioneer species was due to the high mortality of late pioneers and gradually replaced by shade-tolerant species that could grow under the canopy of late pioneers (Walters and Reich 1999; Lilles et al. 2014). Some of the pioneer species found in the rimba are Rhodomyrtus tomentosa, Melastoma polyanthum, and Lycopodium cernuum. In rimba, the existence of pioneer shrubs and herbs was low because the vegetation succession in rimba relatively reached its climax state.

Plant species found in bebak are dominated by semitolerant species, i.e., species that can grow in newly opened and sub-climax ecosystems such as Syzygium lineatum and Lithocarpus blumeanus. Bebak is located not far from rimba, usually bebak is a former field to cultivate Piper nigrum. The number of species in bebak was lesser than rimba due to the younger age of the vegetation succession than in rimba.

The floristic composition of padang was the least among the three habitat types. This is because of the physical conditions in padang that were very open with extreme environmental conditions, thus only species that are tolerant to sunlight and able to adapt to nutrient-poor conditions can survive in padang (Aarssen 1997; Liu et al. 2006; Maire et al. 2012). Pioneer species found in padang included the Fimbrystilis sp., Panicum sp., and L. cernuum. Interestingly, one climax species was also found in padang namely Shorea belangeran, at the seedling stage. This is because the padang ecosystem is directly adjacent to the rimba, so it is possible for seeds to be spread by the wind. According to Whitten et al. (1984), the grassland ecosystem in Bangka and Belitung is dominated by small trees, such as Baeckia frutescens and Melaleuca cajuputi. At the research site of this study, however, the $B$. frutescens did not dominate. This can be caused by the high density of grass in padang, so that the competition for nutrients is quite high, both intraspecies and interspecies (Hau and Corlett 2002).
The dominant plant families in the studied site were Myrtaceae, Clusiaceae, Euphorbiaceae, Rubiaceae, and Fabaceae (Figure 4). The dominance of species from the Myrtaceae might be due to the adaptability of some members of the Myrtaceae family to nutrient-poor heath forest soils. Species of Myrtaceae tend to be well adapted to critical lands such as heath forests and thus dominate the community (MacKinnon et al. 1996; Wisheu et al. 2000; Aiba and Kitayama 2020). Several species of Myrtaceae are also pioneer plants, such as $R$. tomentosa, Rhodamnia cinerea, Syzygium buxifolium. In addition, Annonaceae, Nepenthaceae, Droseraceae, Sapotaceae and other families were also found. In Brunig (1974) study which examined heath forests in Sarawak, relatively many members of the Myrtaceae family were also obtained.

\section{Floristic composition ground cover vegetation}

In this study, ground cover vegetation consisted of seedlings, shrubs, herbs, lianas, rattan, and pandanus. The observation across 100 observation plots in rimba obtained 119 plant species, consisting of 72 species of seedlings, six species of shrubs, 12 species of herbs, 27 species of lianas, and two species of rattan. The most dominant plant species in rimba was Syzygium lepidocarpa with IVI of $20.20 \%$ and a density of $13,475 \mathrm{ind} / \mathrm{ha}$ (Table 1). Plant species with the lowest IVI consisted of several species including Symplocos adenophylla, Memecylon olygoneurum, and Edospermum diadenum with $0.14 \%$. The high heterogeneity of species in rimba is indicated by the occurrence of 23 species in a plot measuring $2 \times 2 \mathrm{~m}^{2}$. The role of biodiversity in forest ecosystem may promote the succession process and support the niche complementarity effect for the mechanism of species coexistence (Carroll et al. 2011; Barrufol et al. 2013; Rodrigues et al. 2019). The five dominant plant species in rimba, which are shown in Table 1 were species from the seedlings of tree species. The presence of shrubs and herbs as pioneer species in rimba were not dominant, because of the condition of the ecosystem in the rimba which relatively reached the climax stage and low light availability.

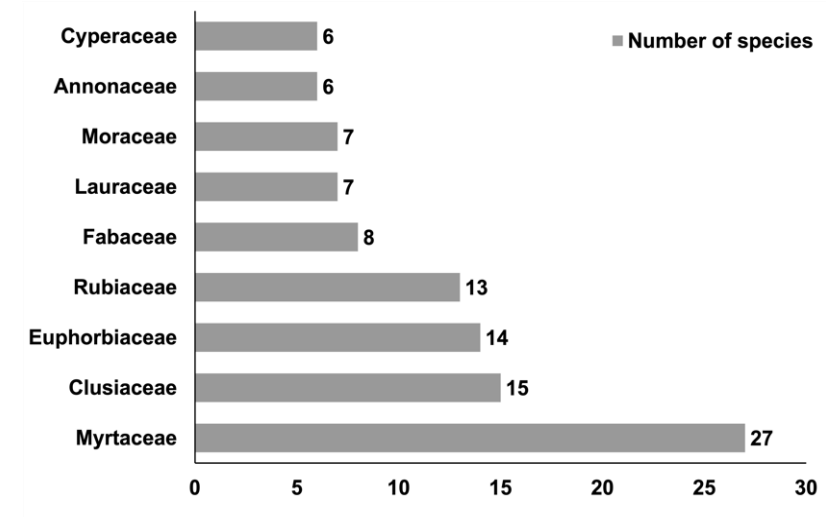

Figure 4. Distribution of number of species in nine dominant plant families in heath forest in East Belitung 
The results of observation in bebak obtained 110 plant species of ground cover vegetation, consisting of 61 species of seedlings, nine species of shrubs, 16 species of herbs, 22 species of lianas, one species of rattan, and one species of pandanus. Species with the highest important values were Guioa pleuropteris $(12.57 \%$ with a density of 3,600 ind/ha) and Syzygium euneura (12.09\% with a density of 3,025 ind/ha) (Table 1). The species with the smallest IVI were Elaeocarpus palembanicus $(0.15 \%$ and a density of $25 \mathrm{ind} / \mathrm{ha}$ ). Some of the lianas found were Lygodium microphyllum, Dalbergia rostrata, and Salacia oblongifolia.

In padang, there were 31 plant species of ground cover vegetation consisting of eight species of seedlings, three species of shrubs, 16 species of herbs, and two species of lianas. The highest IVI of $51.14 \%$ was the Fimbristylis sp. with a density of $85,250 \mathrm{ind} / \mathrm{ha}$ (Table 1).

One unique was Drosera burmanii with IVI of $19.71 \%$. This species is often neglected and rarely found anywhere else, but it occurred in padang (grassland). In addition to D. burmanii, one Nepenthes species was also found in padang, namely Nepenthes gracilis. This funding is in accordance with Whitmore (1984) that state grassland (padang) ecosystem is a suitable habitat of Nepenthes sp. and Drosera sp. Mansur (2007) stated that Nepenthes has a high tolerance for high light intensity and can also grow in a shaded environment. In our study, dry soil conditions did not limit the life of $D$. burmanii. Even in moist and watery soil conditions, Drosera can grow well (Baranyai and Joosten 2016; Witono et al. 2020).

The number of species and individuals of ground cover vegetation in the three habitat types of heath forest was relatively varied. Especially in rimba and bebak, the number of species was quite high. This can be caused by the location of the rimba which was directly adjacent to bebak, so that the spread of seeds of several plant species in bebak can grow in the rimba and vice versa. While in padang, the number of species is relatively small, but the IVI value of the 31 species obtained is very high compared to rimba and bebak. This was the case for Fimbristylis sp. which almost covered the entire floor of padang. This species is a pioneer species that have been existed in padang for a very long time. According to the local community, padang was originally formed as the result of great fires that occurred in ancient times (hundreds of years ago). The fires were triggered by the friction of the trees in the heath forest which was very dry due to the long dry season. Once the land becomes padang, it is very difficult (if not impossible) to be restored as forest again.

\section{Floristic composition of saplings}

Across 100 observation plots in rimba, in total there were 93 species at the sapling stage. The number of saplings obtained was more than the number of seedlings. This shows an inverted pyramid of species structure, meaning that some species might disappear when they grow to a more mature stage. The decline in species number at the saplings stage can be caused by the replacement of pioneer species that are no longer shadetolerant so that they are unable to grow to the saplings (Itoh et al. 1995).

In rimba, the species with the highest IVI was Calophyllum lanigerum $(17.27 \%$ with a density of 900 ind/ha) (Table 2). Five species with the highest IVI as sapling stage were relatively evenly distributed, suggesting that the dominance of the five species in rimba was relatively balanced. According to MacKinnon et al. (1996), the most prominent characteristic of heath forests is to have trees that are low in stature and small in diameter. One of the species at the sapling stage was Tristaniopsis obovata, which was very easily recognizable at the study site because it has red stems and peeling bark. The wood of $T$. obovata is quite hard and is often used as fence wood.

Table 1. Importance value index of five dominant ground cover vegetation in rimba (primary forest), bebak (secondary forest), and padang (grassland) in heath forest in East Belitung.

\begin{tabular}{|c|c|c|c|c|}
\hline Location & Local name & Scientific name & Family & IVI $(\%)$ \\
\hline \multirow[t]{5}{*}{ Rimba } & Samak & Syzygium lepidocarpa & Myrtaceae & 20.20 \\
\hline & Betor Padi & Calophyllum depressinervosum & Clusiaceae & 16.23 \\
\hline & Singkang & Syzygium lineatum & Myrtaceae & 11.24 \\
\hline & Kelebantuian & Syzygium euneura & Myrtaceae & 10.20 \\
\hline & Sisilan & Syzygium rostratum & Myrtaceae & 7.95 \\
\hline \multirow{5}{*}{ Bebak } & Pulas & Guioa pleuropteris & Sapindaceae & 12.57 \\
\hline & Kelebantuian & Syzygium euneura & Myrtaceae & 12.09 \\
\hline & Tenam & Psychotria viridiflora & Rubiaceae & 11.21 \\
\hline & Jemang & Rhodamnia cinerea & Myrtaceae & 10.28 \\
\hline & Seru & Schima wallichii & Theaceae & 9.42 \\
\hline \multirow[t]{5}{*}{ Padang } & Kucai Padang & Fimbristylis sp. & Cyperaceae & 51.14 \\
\hline & Rumput jenis C & Eriocaulon sp. & Eriocaulaceae & 32.67 \\
\hline & Kerupit Padang & Panicum sp. & Poaceae & 27.53 \\
\hline & Drosera & Drocera burmanii & Droceraceae & 19.71 \\
\hline & Rumput Padang bola & Rhynchospora aurea & Cyperaceae & 15.23 \\
\hline
\end{tabular}


Table 2. Importance value index of five dominant saplings in rimba (primary forest), bebak (secondary forest), and padang (grassland) in heath forest in East Belitung.

\begin{tabular}{|c|c|c|c|c|}
\hline Location & Local name & Scientific name & Family & IVI $(\%)$ \\
\hline \multirow[t]{5}{*}{ Rimba } & Betor Belulang & Calophyllum lanigerum & Clusiaceae & 17.27 \\
\hline & Kelebantuian & Syzygium euneura & Myrtaceae & 10.82 \\
\hline & Meleman & Psychotria malayana & Rubiaceae & 10.76 \\
\hline & Jemang & Rhodamnia cinerea & Myrtaceae & 10.75 \\
\hline & Pelawan Kiring & Tristaniopsis obovata & Myrtaceae & 10.59 \\
\hline \multirow[t]{5}{*}{ Bebak } & Kiras & Garcinia hombroniana & Clusiaceae & 21.50 \\
\hline & Jemang & Rhodamnia cinerea & Myrtaceae & 18.11 \\
\hline & Kelebantuian & Syzygium euneura & Myrtaceae & 11.05 \\
\hline & Samak & Syzygium lepidocarpa & Myrtaceae & 10.86 \\
\hline & Seru & Schima wallichii & Theaceae & 10.81 \\
\hline \multirow[t]{3}{*}{ Padang } & Sekuncong & Leptospermum flavescens & Myrtaceae & 88.46 \\
\hline & Gelam & Malaleuca leucadendron & Myrtaceae & 56.41 \\
\hline & Pelawan kiring & Tristaniopsis obovata & Myrtaceae & 55.13 \\
\hline
\end{tabular}

The results of the analysis of sapling vegetation in bebak obtained 76 species. The number of saplings obtained was higher than the number of seedlings. The sapling species with the highest IVI were Garcinia hombroniana $(21.50 \%$ with a density of $1,292 \mathrm{ind} / \mathrm{ha}), R$. cinerea (IVI of $18.11 \%$ and a density of $800 \mathrm{ind} / \mathrm{ha}$ ) (Table 2). Sapling density in bebak $(7,032 \mathrm{ind} / \mathrm{ha})$ was lower than in rimba $(8,804 \mathrm{ind} / \mathrm{ha})$. Several species at the seedling stage were still found at the sapling stage, such as $S$. euneura, R. cinerea, and S. wallichii. Species of annual plants or trees also began to be found, for example Durio zibethinus, Artocarpus integer, and Archidendron pauciflorum. Secondary succession on ex-agricultural land will be dominated by annual plant species for one or two years until they are replaced by plants with longer life cycles (Widiyatno et al. 2017). Vegetation cover in bebak is relatively more open than in rimba. This was due to the fact that bebak has fewer tree stands than in the rimba. In addition, the age of vegetation succession in bebak was only 10 years old, so the succession process is still ongoing. Based on field observation, the 30-years old bebak is almost like rimba, both in terms of species richness and the appearance of a relatively dense formation which might be due to the quality of microsite in both ecosystems (Mayoral et al. 2019).

In padang, there were three plant species at the sapling stage. The sapling species with the highest significance value was Leptospermum flavescens at $88.46 \%$ (Table 2) with a density of $20 \mathrm{ind} / \mathrm{ha}$, equal to the density of $T$. obovata. The grassland ecosystem was indeed dominated by undergrowth. The condition of vegetation in padang was relatively thin and dry due to a lack of nutrients. The $L$. flavescens is a small tree species that are potential bioactive for honey production in Australia (Santos et al. 2021). The leaves are small and somewhat sharp is a form of morphological adaptation to extreme ecosystem conditions to reduce evaporation (Bodner et al. 2015; Fernández-Marín et al. 2020).

\section{Floristic composition of trees}

The results of the analysis of tree-level vegetation in the rimba obtained 51 plant species from 22 families. This number is less than at the seedling and sapling levels. The tree-level was dominated by species from Myrtaceae $(23.5 \%)$. However, the species with the highest importance from the family Theaceae, i.e., S. wallichii with an IVI of $53.36 \%$ and a density of $105 \mathrm{ind} /$ ha (Table 3 ). This species is often found in upland forests in Java. Another species that also had IVI above $50 \%$ is S. lepidocarpa with a density of $144 \mathrm{ind} / \mathrm{ha}$.

One of the typical plant species of the heath forest is Cratoxylum glaucum with an IVI of $15.02 \%$. This species is also the dominant species found in the heath forest of Bako National Park, East Malaysia (Katagiri et al. 1991). Based on diameter class, trees in the rimba were dominated by $10-20 \mathrm{~cm}$ diameter class, which contributed $74.53 \%$ of the 683 individual trees found or $509 \mathrm{ind} / \mathrm{ha}$. According to Onrizal et al. (2005), the highest diameter class distribution of the heath forest stands of Danau Sentarum National Park, West Kalimantan, is $2-10 \mathrm{~cm}$ (6010 ind/ha), while $10-20 \mathrm{~cm}$ had a density of $670 \mathrm{ind} / \mathrm{ha}$.

We obtained 35 plant species belonging to 18 families for trees in bebak. This number is less than at the seedling and sapling levels. Nevertheless, the tree level was also dominated by species from Myrtaceae (17.64\%). The highest IVI at the tree level was $S$. wallichii from the family Theaceae with IVI of $103.00 \%$ with a density of 109 ind/ha (Table 3 ). The $S$. wallichii has a wide range of suitable habitats to grow from an altitude of $100-1600 \mathrm{~m}$ above sea level (Boojh \& Ramakrishnan 1982). This species is also a pioneer species as well as a climax species, so it can grow well in the rimba and bebak (Vaidhayakarn and Maxwell 2010). We also found Archidendron pauciflorum which is a plant species that is commonly cultivated. Another species found was Ilex cymosa which usually lives in somewhat open vegetation, and is quite well adapted to fire (Whitmore 1984). 
Table 3. Important value index of five dominant trees in rimba (primary forest) and bebak (secondary forest) in heath forest in East Belitung, Indonesia

\begin{tabular}{llllc}
\hline Location & Local name & Scientific name & Family & IVI $(\%)$ \\
\hline Rimba & Seru & Schima wallichii & Theaceae & 53.36 \\
& Samak & Syzygium lepidocarpa & Myrtaceae & 52.15 \\
& Jemang & Rhodamnia cinerea & Myrtaceae & 16.07 \\
& Gerunggang & Cratoxylum glaucum & Clusiaceae & 15.02 \\
& Betor Padi & Calophyllum depressinervosum & Clusiaceae & 14.69 \\
& & Schima wallichii & Theaceae & 103.00 \\
Bebak & Seru & Archidendron pauciflorum & Fabaceae & 48.18 \\
& Jering & Syzygium lepidocarpa & Myrtaceae & 15.48 \\
& Samak & Cinnamomum parthenoxylon & Lauraceae & 13.10 \\
& Medang kalong & Ilex cymosa & Aquifoliaceae & 12.37 \\
\hline
\end{tabular}

Trees that grow in padang have very hard, dry, and very rare wood. The results of the analysis of tree-level vegetation in padang obtained two plant species. The treelevel species with the highest importance were $L$. flavescens at $180.60 \%$ with a density of $2 \mathrm{ind} / \mathrm{ha}$ and sapling Combretocarpus rotundatus at $119.40 \%$ with a density of $1 \mathrm{ind} / \mathrm{ha}$. The two species were only found in one observation. The low number of trees in padang implies the level of vulnerability of this area from disturbance. The bark of L. flavescens is very hard and dry which is an adaptation to the extreme environment. Acidic and nutrient-poor soil conditions do not support the survival of other species found at the seedling to sapling and tree levels. However, this is indeed a characteristic of the desert ecosystem (Eldridge et al. 2018).

In general, it can be seen that there are differences in species that dominate in each type of heath forest and at each growth stage. The species at the seedling level that dominated in the rimba was S. lepidocarpa, whereas this species did not dominate at the sapling and tree levels. At the tree level, S. wallichii dominated in rimba and bebak. The composition and dominance of vegetation in an ecosystem will change in the future due to the differences in the survival rate of a species against the dynamics of the ecosystem both physically and biotically as well as external disturbances (Comita et al. 2014; Moustakas and Evans 2015; Zhu et al. 2018).

\section{Species diversity, richness, and evenness at three habitat types of heath forest}

The value of species diversity of saplings and trees in rimba (i.e., 3.73 and 3.09) was higher than in bebak and padang (Figure 5.A). The more climax of an ecosystem it will be followed by an increase in the number of species that can live there at the seedling level and only certain species can survive. Therefore, a decrease in the value of diversity from the seedling level to the tree level can occur. A change in the dominant species during the pioneer stage will result in an adjustment in the interspecific relationship of the community (Aiba et al. 2012; García-Cervigón et al. 2013).

The seedling's diversity in rimba was lower than that in bebak (i.e., 3.86 and 4.03). This could be due to the number of individuals of each species in rimba was not evenly distributed (Ludwig et al. 1988). Padang had a very low diversity value of seedlings, saplings, and trees (i.e., 2.34,
1.07, and 0.67) when compared to bebak and rimba. The diversity index varies depending on the forest type and growth stages. Changes in the species diversity index occur because of the biological properties of the forest, which are always growing and developing (Kissinger 2002). Furthermore, changes in diversity can occur quickly because of human actions or natural processes.

Rimba and bebak had similar species richness index at the seedling stage with 14.35 and 14.44 , respectively (Figure 5.B). The closeness of ecosystem types may also contribute to this slight variance. Because bebak was a secondary forest that had been utilized for shiftingcultivation and had been abandoned for ten years, there were many species present there, particularly pioneer species (Guimarães Vieira and Proctor 2007; Karthik et al. 2009). Some species have a tendency for rapidly colonizing pioneer stands (Li et al. 2005). The total number of individuals of all species has an impact on the value of species richness. The value of richness decreases as the total number of individuals of all species in an ecosystem grows. On the other hand, the value of richness increases where at the same number of species but has a smaller total number of individuals of all species (Ludwig et al. 1988).

Seedlings, saplings, and trees had the lowest species richness in the grassland ecosystem (padang) with 3.27, 0.78 , and 0.91 , respectively. Only three species were found at the sapling stage with a total of 52 individuals per hectare. Only two species were found at the tree stage, equal to three individuals per hectare. This is an extremely modest number, indicating that the sapling and tree species richness in padang was very low. Bebak had the highest seedling plant species evenness value compared to rimba and padang. In padang, the value of plant species evenness at the seedling and tree stage was the greatest. In padang, only two species with a total of three individuals which causes the evenness value of trees plant species in padang to be higher, namely 0.97 (Figure 5.C). In rimba, the evenness value of the trees stage was 0.78 which is due to the number of individuals from 51 tree species. Compared to rimba, padang ecosystem had more severe habitat conditions, and the composition of herbaceous and shrub species was shown to be affected by environmental filtering and dispersal limitation, with the niche process of environmental filtering playing a leading role (LebrijaTrejos et al. 2010). 


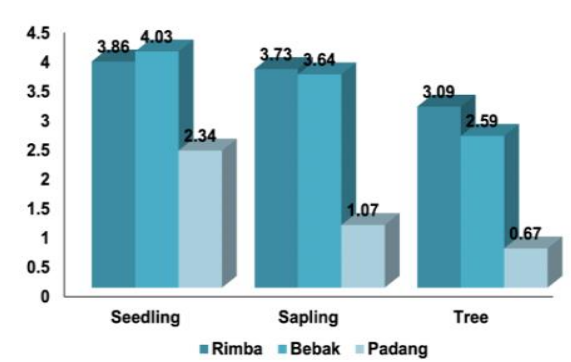

A



B

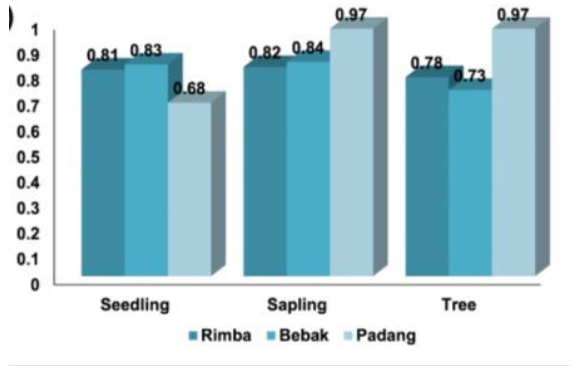

C

Figure 5. Biodiversity indicators of vegetation at different growth stages in three habitats of heath forest in East Belitung: A. Species diversity index; B. Species richness index; and C. Species evenness index

An essential goal in community ecology is to understand the processes that drive community assembly. Several mechanisms ranging from entirely deterministic to stochastic have been offered to explain the high number of species present in some ecological communities (Kraft et al. 2015). Many plant species have specific abiotic requirements for successful germination, and thus the germination stage represents the first point at which habitat filtering can occur. The potential for a particular functional type such as trees, shrubs, herbs, and lianas to drive forest dynamics could have important implications for forest management (Lebrija-Trejos et al. 2010; Loiola et al 2015). Understanding the ecological role of environmental heterogeneity and plant functional types through functional traits approach, species-habitat association, and population dynamics are essential because it provides basic information about plant community dynamics. We suggested that the presence of species composition in the three habitat types of heath forest in Belitung Island is an essential plant resource to be conserved and sustainably utilized. Establishing reserve areas to protect natural habitat and biodiversity is encouraged to provide proper ecosystem function for the people and nature. The encouragement to conduct several ecological-based research is also necessary to improve global knowledge of heath forests in the tropical region.

\section{REFERENCES}

Aarssen LW. 1997. High productivity in grassland ecosystems: Effected by species diversity or productive species? Oikos 80: 183-184. DOI: $10.2307 / 3546531$.

Aiba M, Takafumi H, Hiura T. 2012. Interspecific differences in determinants of plant species distribution and the relationships with functional traits. J Ecol 100: 950-957. DOI: 10.1111/j.13652745.2012.01959.x.

Aiba S-I, Kitayama K. 2020. Light and nutrient limitations for tree growth on young versus old soils in a Bornean tropical montane forest. J Plant Res 133: 665-679. DOI: 10.1007/s10265-020-01217-9.

Baranyai B, Joosten H. 2016. Biology, ecology, use, conservation and cultivation of round-leaved sundew (Drosera rotundifolia L.): a review. Mires Peat 18. DOI: 10.19189/MaP.2015.OMB.212.

Barrufol M, Schmid B, Bruelheide H, Chi X, Hector A, Ma K, Michalsk S, Tang Z, Niklaus PA. 2013. Biodiversity promotes tree growth during succession in subtropical forest. Plos One 8: e81246. DOI 10.1371/journal.pone.0081246.

Becker P, Wong M. 1993. Drought - induced mortality in tropical heath forest. J Trop For Sci 5: 416-419.
Bird MI, Taylor D, Hunt C. 2005. Palaeoenvironments of insular Southeast Asia during the Last Glacial Period: a savanna corridor in Sundaland? Quat Sci Rev 24, 2228-2242. DOI: 10.1016/j.quascirev.2005.04.004.

Bodner G, Nakhforoosh A, Kaul HP. 2015. Management of crop water under drought: a review. Agro Sustain Dev 35: 401-442. DOI: 10.1007/s13593-015-0283-4.

Brunig E. 1974. Ecological Studies in The Kerangas Forests of Sarawak and Brunei. Borneo Literature Bureau Malaysia.

Budiharta S, Meijaard E, Erskine PD, Rondinini C, Pacifici M, Wilson KA. 2014. Restoring degraded tropical forests for carbon and biodiversity. Environ Res Lett 9, 114020. DOI: 10.1088/17489326/9/11/114020.

Carroll IT, Cardinale BJ, Nisbet RM. 2011. Niche and fitness differences relate the maintenance of diversity to ecosystem function. Ecology 92: 1157-1165. DOI: 10.1890/10-0302.1.

Chesson P. 2000. Mechanisms of maintenance of species diversity. Ann Rev Ecol Syst 31: 343-366. DOI: 10.1146/annurev.ecolsys.31.1.343.

Comita LS, Queenborough SA, Murphy SJ, Eck JL, Xu K, Krishnadas M, Beckman N, Zhu Y, Gomez-Aparicio L. 2014. Testing predictions of the Janzen-Connell hypothesis: a meta-analysis of experimental evidence for distance- and density-dependent seed and seedling survival. J Ecol 102: 845-856. DOI: 10.1111/1365-2745.12232

Davies S, Becker P. 1996. Floristic composition and stand structure of mixed dipterocarp and heath forests in Brunei Darussalam. J Trop For Sci 8 (4): 542-569.

Dodo, Hidayat S. 2020. The structure, composition, and threatened plants in The Kinarum Protected Forest, South Kalimantan, Indonesia. Biodiversitas 21 (6): 2603-2618. DOI: 10.13057/biodiv/d210632.

Eldridge DJ, Maestre FT, Koen TB, Delgado-Baquerizo M. 2018. Australian dryland soils are acidic and nutrient-depleted, and have unique microbial communities compared with other drylands. J Biogeogr 45: 2803-2814. DOI: 10.1111/jbi.13456.

Fakhrurrazi Y. 2001. Satuan-Satuan Lansekap dan Keanekaragaman Tumbuhan Buah-Buahan Liar Edibel Dalam Kehidupan Masyarakat Melayu Belitung. [Thesis]. Institut Pertanian Bogor, Bogor [Indonesian]

Fernández-Marín B, Gulias J, Figueroa CM, Iniguez C, Clemente-Moreno MJ, Nunes-Nesi A, Fernie AR, Cavieres LA, Bravo LA, GraciaPlazaola JI. 2020. How do vascular plants perform photosynthesis in extreme environments? An integrative ecophysiological and biochemical story. The Plant J 101: 979-1000. DOI: 10.1111/tpj.14694.

García-Cervigón AI, Gazol A, Sanz V, Camarero JJ, Olano JM. 2013. Intraspecific competition replaces interspecific facilitation as abiotic stress decreases: The shifting nature of plant-plant interactions. Perspect Plant Ecol Evol Syst 15: 226-236. DOI: 10.1016/j.ppees.2013.04.001.

Guimarães Vieira I, Proctor J. 2007. Mechanisms of plant regeneration during succession after shifting cultivation in eastern Amazonia. Plant Ecol 192: 303-315. DOI: 10.1007/s11258-007-9327-4.

Hattori D, Kenzo T, Shirahama T, Harada Y, Kendawang J, Ninomiya I, Sakurai K. 2019. Degradation of soil nutrients and slow recovery of biomass following shifting cultivation in the heath forests of Sarawak, Malaysia. For Ecol Manag 432: 467-477. DOI: 10.1016/j.foreco.2018.09.051. 
Hau B, Corlett R. 2002. A survey of trees and shrubs on degraded hillsides in Hong Kong. Memoirs of the Hong Kong Natural History Society 25: 83-94.

Hossen S, Hossain MK, Hossain MAA, Uddin MF. 2021. Quantitative assessment of tree species diversity of Himchari National Park (HNP) in Cox's Bazar, Bangladesh. Asian J For 5 (1): 1-7.

Itoh A, Yamakura T, Ogino K, Seng L. 1995. Survivorship and growth of seedlings of four dipterocarp species in a tropical rainforest of Sarawak, East Malaysia. Ecol Res 10 (3): 327-338. DOI: 10.1007/BF02347859.

Karthik T, Veeraswami GG, Samal PK. 2009. Forest recovery following shifting cultivation: an overview of existing research. Trop Conserv Sci 2: 374-387. DOI: 10.1177/194008290900200401.

Katagiri S, Yamakura T, Lee SH. 1991. Properties of soils in Kerangas forest on sandstone at Bako National Park, Sarawak, East Malaysia. Japan J Southeast Asian Stud 29: 35-48.

Kissinger. 2002. Keanekaragaman Jenis Tumbuhan, Struktur Tegakan, dan Pola Sebaran Spasial Beberapa Spesies Pohon Tertentu di Hutan Kerangas. [Thesis]. Institut Pertanian Bogor, Bogor [Indonesian]

Kraft NJB, Adler PB, Godoy O, James EC, Fuller S, Levine JM. 2015 Community assembly, coexistence and the environmental filtering metaphor. Funct Ecol 29: 592-599. DOI: 10.1111/1365-2435.12345.

Kusmana C. 1997. Metode Survey Vegetasi. PT. Penerbit Insitut Pertanian Bogor, Bogor. [Indonesian]

Laliberté E, Zemunik G, Turner BL. 2014. Environmental filtering explains variation in plant diversity along resource gradients. Science 345: 1602-1605. DOI: 10.1126/science.1256330.

Lebrija-Trejos E, Pérez-García EA, Meave JA, Bongers F, Poorter L. 2010. Functional traits and environmental filtering drive community assembly in a species-rich tropical system. Ecology 91: 386-398. DOI: $10.1890 / 08-1449.1$

Li ZQ, Bogaert J, Nijs I. 2005. Gap pattern and colonization opportunities in plant communities: effects of species richness, mortality, and spatial aggregation. Ecography 28: 777-790. DOI: 10.1111/j.2005.0906-7590.04261.x

Lilles EB, Astrup R, Lefrancois ML, Coates KD. 2014. Sapling leaf trai responses to light, tree height and soil nutrients for three conifer species of contrasting shade tolerance. Tree Physiol 34: 1334-1347. DOI: 10.1093/treephys/tpu092.

Liu P, Huang J, Han X, Sun OJ, Zhou Z. 2006. Differential responses of litter decomposition to increased soil nutrients and water between two contrasting grassland plant species of Inner Mongolia, China. Appl Soil Ecol 34: 266-275. DOI: 10.1016/j.apsoil.2005.12.009.

Loiola PP, Scherer-Lorenzen M, Batalha MA. 2015. The role of environmental filters and functional traits in predicting the roo biomass and productivity in savannas and tropical seasonal forests. For Ecol Manag 342: 49-55. DOI: 10.1016/j.foreco.2015.01.014.

Ludwig JA, Reynolds JF, Quartet L, Reynolds J. 1988. Statistical Ecology: A Primer in Methods and Computing. John Wiley \& Sons.

Luizão FJ, Luizão RC, Proctor J. 2007. Soil acidity and nutrien deficiency in central Amazonian heath forest soils. Plant Ecol 192: 209-224. DOI: 10.1007/s11258-007-9317-6.

MacKinnon K, Hatta G, Halim H, Mangalik A. 1996. The Ecology of Kalimantan. Periplus Editions, Jakarta, Indonesia.

Maire V, Gross N, Borger L, Proulx R, Wirth C, Pontes L, Soussana J-F Louault F. 2012. Habitat filtering and niche differentiation jointly explain species relative abundance within grassland communities along fertility and disturbance gradients. The New Phytol 196: $497-$ 509. DOI: 10.1111/j.1469-8137.2012.04287.x.

Mansur M. 2007. Keanekaragaman jenis Nepenthes (kantong semar) dataran rendah di Kalimantan Tengah. Jurnal Ilmiah Nasional 8 (5) 335-339. [Indonesian]

Mayoral C, van Breugel M, Turner BL, Asner GP, Vaughn NR, Hall JS 2019. Effect of microsite quality and species composition on tree growth: A semi-empirical modeling approach. For Ecol Manag 432: 534-545. DOI: 10.1016/j.foreco.2018.09.047
Moustakas A, Evans MR. 2015. Effects of growth rate, size, and light availability on tree survival across life stages: a demographic analysis accounting for missing values and small sample sizes. BMC Ecol 15: 6. DOI: 10.1186/s12898-015-0038-8.

Mueller-Dumbois D, Ellenberg H. 1974. Aims and Methods of Vegetation Ecology. John Willey and Sons, New York

Oktavia D, Setiadi Y, Hilwan I. 2015. The comparison of soil properties in heath forest and post-tin mined land: Basic for ecosystem restoration. Proc Environ Sci 28: 124-131. DOI: 10.1016/j.proenv.2015.07.018.

Onrizal O, Kusmana C, Saharjo BH, Handayani IP, Kato T. 2005. Species composition and structure of ex-burned heath forest in Danau Sentarum National Park, West Kalimantan. Biodiversitas 6 (4): 263265. DOI: 10.13057/biodiv/d060410.

Rodrigues AC, Villa PM, Ali A, Ferreira-Júnior W, Neri AV. 2019. Finescale habitat differentiation shapes the composition, structure and aboveground biomass but not species richness of a tropical Atlantic forest. J For Res 31 (5): 1599-1611. DOI: 10.1007/s11676-01900994-X.

Santos AA, Hancox TJJ, Picanço MC, Delaporte K, Hogendoorn K. 2021. Potential distribution of Leptospermum species (Myrtaceae) in Australia for bioactive honey production purposes. N Z J Crop Hort Sci 1-12. DOI: 10.1080/01140671.2021.1951306.

Sellan G, Thompson J, Majalap N, Brearley FQ. 2019. Soil characteristics influence species composition and forest structure differentially among tree size classes in a Bornean heath forest. Plant Soil 438: 173 185. DOI: $10.1007 / \mathrm{s} 11104-019-04000-5$.

Templeton LK, Neel MC, Groffman PM, Cadenasso ML, Sullivan JH. 2019. Changes in vegetation structure and composition of urban and rural forest patches in Baltimore from 1998 to 2015. For Ecol Manag 454: 117665. DOI: 10.1016/j.foreco.2019.117665.

Tyree MT, Patino S, Becker P. 1998. Vulnerability to drought-induced embolism of Bornean heath and dipterocarp forest trees. Tree Physiol 18: 583-588. DOI: 10.1093/treephys/18.8-9.583.

Vaidhayakarn C, Maxwell J. 2010. Ecologycal status of the lowland decidious forest in Chang Kian Valley, Chiang Mai, Northern Thailand. Maejo Inter Sci Tech 4 (20): 268-317.

Vockenhuber EA, Scherber C, Langenbruch C, Meißner M, Seidel D, Tscharntke T. 2011. Tree diversity and environmental context predict herb species richness and cover in Germany's largest connected deciduous forest. Perspect Plant Ecol Evol Syst 13 (2): 111-119. DOI: 10.1016/j.ppees.2011.02.004.

Walters MB, Reich PB. 1999. Low-light carbon balance and shade tolerance in the seedlings of woody plants: do winter deciduous and broad-leaved evergreen species differ? New Phytol 143: 143-154. DOI: $10.1046 /$ j.1469-8137.1999.00425.x.

Whitmore T. 1984. Tropical Rainforest of the Far East. Clarendon Press, Oxford.

Whitten A, Anwar J, Damanik S, Hisyam N. 1984. The Ecology of Sumatra. UGM Press, Yogyakarta.

Widiyatno, Budiadi, Suryanto P, Rinarno YDBM, Priyanto SD, Hendro Y, Hosaka T, Numata S. 2017. Recovery of vegetation structure, soil nutrients and late-succession species after shifting cultivation in Central Kalimantan, Indonesia. J Trop For Sci 29 (2): 151-162.

Wisheu I, Rosenzweig M, Olsvig-Whittaker L, Shmida A. 2000. What makes nutrient-poor Mediterranean heathlands so rich in plant diversity? Evol Ecol Res 2 (7): 935-955.

Witono JR, Usmadi D, Purnomo DW, Safarinanugraha D, Pakiding Y, Netoseno N. 2020. Autecology of Drosera burmanni in the Wolobobo Botanic Gardens, Ngada District, Flores Island, Indonesia. Biodiv J Biol Div 21 (5): 2137-2145. DOI: 10.13057/biodiv/d210542.

Zhu Y, Queenborough SA, Condit R, Hubbell SP, Ma KP, Comita LS. 2018. Density-dependent survival varies with species life-history strategy in a tropical forest. Ecol Lett 21 (4): 506-515. DOI: 10.1111/ele.12915 